\title{
交通情報によるドライバーの経路新導効果に 関寸る研究
}

\section{小林潔司*・井川 修**}

公共主体による経路誘導情報の提供は,「情報の受信一経路選択一経験情報の蓄積」 という学習過程を経て，1）短期的にはドライバーの経路選択に，2）長期的にはドライ バーの期待形成に影響を及ぼす. 本研究では合理的期待形成仮説に基づいた経路選択モ デルを拡張し, 上述の学習過程を合理的期待形成過程としてモデル化する. さらに，経 路情報がドライバーの経路選択と期待形成に及ぼす影響を検討するための分析枠組を提 示し，望ましい経路誘導をめざした情報提供方法に関して考察する.

Key Words : automobile navigation, route guidance information, route choice model, rational expectations, informational role of information

\section{1.はじめに}

Navigation systems 等の経路誘導方策は, 道路交通 の重要な制御手段になりつつある.これらの方策は，公 共主体がすべての（一部の）ドライバーに経路の走行条 件に関する情報を事前に与え，ドライバーの経路選択行 動を間接的に誘導することを目的亡する．経路誘導情報 の提示が経路誘導効果を発揮するためには，公共主体と ドライバーの間に何らかの情報の非対称性が存在するこ とが前提となる，つまり，ドライバーが有する私的な経 路情報には不確実性が存在し，公共主体による情報提示 が不確実性を軽減するように働く必要がある.

公共主体によるドライバーの経路誘導を取り扱った研 究事例はいくつかある11-31. これらの研究では公共主体 がドライバーの経路選択に強制力を行使することを前提 としており, 経路誘導情報の提供がドライバーの経路選 択に及ぼす影響を分析できる枠組にはなっていない．経 路誘導情報の提供は，ドライバーの「情報の受信一経路 選択一経験情報の蓄積」という過程を経て，1）短期的 にはドライバーの経路選択に直接影響を及ぼし，2）長 期的には，ドライバーの期待形成に影響を及ぼす。した がって，ドライバーの経路誘導をめざした情報提供シス テムを設計する場合, 経路誘導情報に対するドライバー の短期的 ・長期的反応行動を考慮に入れることが不可欠 である. 本研究では, 経路誘導情報の提供がドライバー の経路選択之期待形成に及ぼす影響を検討するための分 析枠組を提示し, ドライバーの望ましい経路誘導をめざ した情報提供方法に関して考察することとする.

経路情報の役割を明示的に考慮したドライバーの経路 選択モデルに関していくつかの研究4),5)がなされている.

\footnotetext{
*正会員 工博 鳥取大学教授 工学部社会開発システム工学 科 ( $=680$ 鳥取市湖山町南 4-101)

**正会員 工修 (株)鴻池組
}

小林 $\left.{ }^{4}\right)$ は「不確実な経路の走行条件に関して，ドライバー が利用可能な経路情報に基づき合理的な予測を行い期待 効用を最大にするような経路を選択する」という合理的 期待（Rational Expectations：以下， REと略す）形成 仮説を設け，ドライバーの合理的期待均衡に関して分析 している. ドライバーが学習行動を通じて, 主観的期待 を更新する過程をべイズ学習モデルとして表現し，ドラ イバーの RE 形成過程について分析している51.これら の経路選択モデルの目的は, ドライバーが経路選択を繰 り返すことにより経験情報を蓄積し, 経路走行条件に関 する期待を形成するメカニズムを記述する点にある.

本研究では, 経路誘導情報の提供がドライバーの経路 選択之期待形成に及ぶ影響を把握するための分析枠組を 提示し，ドライバーの望ましい経路誘導をめざした情報 提供システムの設計方法を提案する. 以下，2. で，本研 究の分析の視点を明確にし，3.において経路誘導情報が 期待形成に及ぼす影響について考察する. 4.で, ドライ バーの経路選択・期待形成モデルを定式化し，5.で経路 誘導情報システムの設計方法について考察する.6. では, 数值計算事例を通じて経路誘導情報の提供がドライバー の経路選択に及ぼす影響について考察する.なお, 本研 究の分析では，筆者らが提案した RE 形成モデル ${ }^{5}$ を用 いることとする. しかし, 分析の目的に沿ってモデルの 内容を若干拡張する必要が生じた。したがって, 本稿の 3,4 , では, 不必要な混乱を避けるために, 前稿との重 複を恐れずモデルの再定式化を試みている. モデルの誘 導等の詳細については前稿5)を参照されたい.

\section{2. 分析の基本的枠組み}

\section{（1）問 題 設 定}

公共主体が経路誘導情報 (route guidance information：以下, 交通情報と略す).の提供を通じてドライバー の経路選択を間接的に制御する問題を考える. 公共主体 


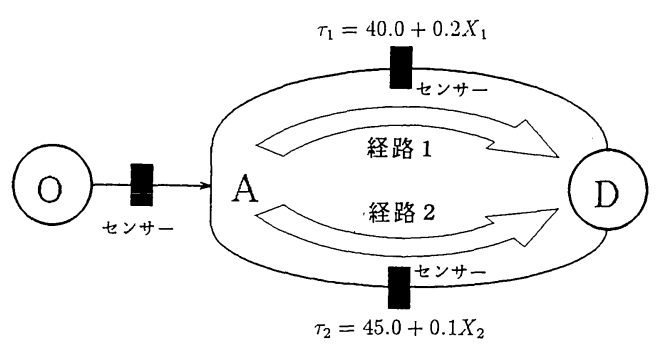

図一1 対象とする経路誘導問題

は交通情報を提供するが，ドライバーの経路選択に対し て強制力を行使しない. ドライバーは経路の自由選択が 可能である. ドライバーは交通情報が十分に信頼性に足 るものと判断すれば, 交通情報に従うインセンティブを 有する、いま, 議論を明確にするために図一1に示す問 題を考える．各ルートには内々交通による混雑が生じる が, 分岐点を通過するドライバーはその状況を知らない. 公共主体は, 各時点の内々交通量に基づいて各経路の走 行時間を予測する．そのうえで，走行時間が最小となる であろう経路を推定し，その結果を分岐的の通過ドライ バーに通知する. 仮に, すべての通過ドライバーが公共 主体が指定した経路を利用し，結果的に指定されなかっ た経路の方が走行時間が短くなったとしよう。このよう な状況が続けば，ドライバーの中には交通情報の信頼性 に疑問を持ち, 指定されない経路を選択しようとする者 も現われよう.ある交通情報が提示された時よ゙のような 走行状態が実現するかは, その時点におけるドライバー の経路選択の結果として内生的に決定される. ドライ バーは経路選択を繰り返し, 交通情報がどの程度の信頼 性を有しているかを学習する，学習結果はドライバーの 選択行動に影響を及ぼし, 結果的に交通情報の信頼性自 体に影響を与える。したがって，公共主体が交通情報の 提示方法を検討するためには，このようなドライバーの 長期学習過程を明示的に考慮することが不可欠となる。

\section{（2）経路誘導問題の基本構成}

交通情報によるドライバーの経路誘導効果を検討する 問題を経路誘導問題と呼ぶ．交通情報を提供するために は，何らかの方法で道路網における交通流の状態をモ二 タリングし，実現するであろう各経路の走行状態を事前 に予測する必要がある.モニタリング方法は多々あるが, ここではネットワーク上にいくつかのセンサーを配置す る場合を想定する．ここで，時間軸を離散化しよう．公 共主体は，モ二タリング地点で当該期の期首までに観測 された交通情報に基づいて，当該期に実現するであろう 各経路の走行時間を予測する. そのうえで, 公共主体は, 当該期にある地点（例えば，図一1の分岐点）を通過す るドライバーに交通情報を提供する.

本研究では, 公共主体がモニタリング情報に基づいて
当該期に実現するであろう各経路の走行時間を予測する メカニズム $\Gamma$ を予測メカニズムと呼ぶ. 予測メカニズ 厶を設計する場合, 公共主体が提供した交通情報に対し てドライバーがよ゙のように反応するかを明示的に考慮す る必要がある. 公共主体は予測結果を用いてドライバー に提供すべき交通情報の内容を決定する. その際，「す べての通過ドライバーに情報を与えるか否か」,「どの程 度詳細な情報を提供するか」等, 交通情報をよ゙のように ドライバーに提供すべきかという問題が生じる，予測結 果に基づいて交通情報の内容を決定するルール $\Lambda$ を情 報提供ルールと呼ぶ.このように交通情報の提供問題は, 1) モニタリングシステムの設計 (センサーの最適配置), 2）公共主体の予測メカニズム $\Gamma$ の設計，3）交通情報 提供ルール $\Lambda$ の設計, という部分問題により構成され る複合的な計画問題となっている。本研究では，モ二夕 リングシステムを与件と考え，2，，3）の設計問題に焦 点を絞る. 交通情報の提供ルールを変更すれば, ドライ バーの経路選択行動が変化し, 結果として各経路の走行 状態も変化する. したがって, 予測メカニズムと情報提 供ルールの設計問題は互いに密接に関連している. 本研 究では, 公共主体がドライバーの厚生状態に基一ういて, 予測メカニズム $\Gamma$, 情報提供ルール $\Lambda$ の望ましさを検 討する問題を考えよう.この時, 経路誘導問題は, ドラ イバーの厚生により定義される社会的厚生関数をできる 限り大きくするような予測メカニズム $\Gamma$, 情報提供ルー ル $\Lambda$ を設計する問題として定式化できる.このような 経路誘導システムの設計問題は 5 , で考察する.

\section{3. 交通情報と期待形成}

\section{（1），経路情報の種類}

経路選択に直面しているドライバーは実現する経路の 走行条件を確定的に把握できない. 彼は, 経路選択に先 だって, 獲得可能な情報や過去の経験に基づいて各経路 の走行条件を主観的に予測し, 期待効用を最大にする経 路を選択すると考える. 小林 ${ }^{4}$ は, ドライバーが走行条 件の予測に用いる情報を「経路情報」と呼び，1）道路 網の物的特性，機能特性に関する情報，2）公共主体が 提示する「交通情報」，3）天候・曜日等の外的条件に関 する情報，4）ドライバーが有するその時々の私的情報, 5）過去の走行結果に関する経験情報に分類している. 1)，2），3）はドライバーが事前にかなり正確に把握でき る共有情報である．共有情報とは複数のドライバーが共 有する情報であり，さらに共有化しているということを すべてのドライバーが知っているような情報を意味す $3^{6)}$. 本稿でも前稿 ${ }^{4}$ と同様に，ドライバーは1）に関す る情報を知悉していると考える．また，ある一定の外的 条件のもとでのドライバーの経路選択行動に分析の焦点 を絞る.したがって，共有情報として 2) のみをとりあ 
げる. 一方，4，5）は個々のドライバーが私的に占有す る情報であり，他人がその内容を知ることはできない ${ }^{7)}$. ドライバーは交通情報に必ずしも常に従うわけではな い. その時々の気まぐれや局所的なできごと(私的情報) がドライバーの経路選択に影響を及ぼす。また，ドライ バーは過去の経験情報に基づいて交通情報の信頼性や各 経路の走行状態を判断する.このように経験情報はドラ イバーの期待形成に影響を及ぼす。

\section{（2） 効用関数の定式化}

ドライバーは，2）交通情報と５）過去の経験情報に基 づいて各経路の走行状態を主観的に予測する. ドライ バーが予測した各経路の走行時間分布を主観的期待と呼 ぶ. ドライバーの選択行動は，このような主観的期待だ けでなく，その時々の気まぐれや偶然的な出来事の影響 を受ける。ここでは，私的情報 4) を，ドライバー $s$ が 認知するその時々の外的状況や嗜好状態亡考え, 状態変 数 $\omega_{s}=\left\{\omega_{a s} ; a \in \delta_{s}\right\}$ で表す. $\omega_{a s} \in \Omega_{a s}$ はドライバー $s$ の経路 $a$ に特有な私的情報， $\delta_{s}$ は，ドライバー $s$ が選 択可能な経路集合， $\Omega_{a s}$ は私的情報の集合である. $\omega_{a s}$ はその時々の気分や偶然性によって変動する確率変数で あり, 確率密度関数 $\phi\left(\omega_{a s}\right)$ に従って変動すると考える. 経路選択を行うドライバーの集合を $S=\{1, \cdots, Q\}$ で 表わす。経路選択を行うドライバ一の数 $Q$ は，各期に よって変動する確率変数であり, $S$ 自体も期によって変 動する母集団過程 ${ }^{8)}$ となっている．ドライバーが有する 私的情報の組を $\mu=\left\{Q,\left(\omega_{1}, \cdots, \omega_{Q}\right)\right\}$ と定義する． $\mu$ は私的情報の不完備性を明示的に表現した情報集合であ り情報構造亡呼ぶ。私的情報は確率変数であり, 情報構 造自体が確率的に変動する。 ある時点でドライバー $s$ が 利用した私的情報の実現值を $\widehat{\omega}_{s}$, 実現した情報構造を $\hat{\mu}$ と表す. ドライバー $s$ のみが私的情報 $\widehat{\omega}_{s}$ を知ること が可能であり，ビのような情報構造 $\hat{\mu}$ が実現している かは誰も知らない。情報構造は各期で変化し, それに応 じてドライバーの経路選択行動も各期で多様に変化す る. 私的情報 $\omega_{s}$ は, 経路選択に影響を与える偶然的・ 局所的な確率的要因であり, 経路選択の直前にその值が $\widehat{\omega}_{s}$ に確定する。私的情報はドライバーの心理的要因の 効果を表わし，その時点の経路選択のみに影響を及ぼす と考える. ドライバー $s$ の経路 $a$ に対する効用を

$U_{a s}=U\left(\tau_{a}, \widehat{\omega}_{a s}\right)$

と表現する.なお，Uはノイマン=モルゲンシュテル ン型効用関数, $\tau_{a}$ は経路 $a$ の走行時間, $\partial U / \partial \tau_{a} \leq 0$, $\partial^{2} U / \partial \tau_{a}^{2} \geq 0$ を仮定する.

\section{（3）交通情報と主観的期待}

本研究では基本的には筆者らによる REE 形成モデ ル ${ }^{5)}$ 用いるが，以下では交通情報の役割を明示的に考 慮できるようにモデルの内容を拡張することとする. 経 路 $a$ の走行時間 $\tau_{a}$ は, 内々交通量や通過ドライバーの
経路選択の結果に依存し,その值は各期ごとに変動する. 走行時間 $\tau_{a}\left(a \in \delta_{s}\right)$ は確率変数であり, ドライバーは 経路選択に先だってその值を確定的に把握できない。 ド ライバーは経路選択にあたって各経路の走行時間分布を 予測する. ドライバー $s$ の経路 $a$ の走行時間 $\tau_{a}$ に対す る主観的期待 $\pi_{a s}(\phi)$ を確率密度関数 $\pi_{a s}\left(\tau_{a} ; \phi\right)$ で表 わす. $\phi$ は交通情報の提示がない場合を表わす。ドライ バーは主観的期待に基づいた期待効用 $V\left(\widehat{\omega}_{a s} ; \phi\right)$

$$
V\left(\widehat{\omega}_{a s} ; \phi\right)=\int U\left(\tau_{a}, \widehat{\omega}_{a s}\right) \pi_{a s}\left(\tau_{a} ; \phi\right) d \tau_{a}
$$

が最大となる経路を選択すると考える。

公共主体が交通情報を提供した場合を考える，交通情 報の内容をメッセージと呼び，それを状態変数 $e \in \eta$ に より表現する．図一1において選択を推奨する経路を指 示する場合を考えよう。メッセージとして「経路 1 を利

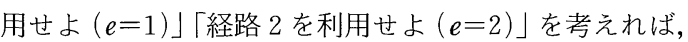
メッセージ集合は $\eta=(1,2)$ となる. ドライバーは, 異なるメッセージ $e \in \eta$ に対して異なる主観的期待を形 成すると考える. メッセージ $e$ の下での主観的期待を独 立な確率密度関数の組 $\pi_{s}(e)=\left\{\pi_{a s}\left(\tau_{a} ; e\right), a \in \delta_{s}\right\}$ によ り表現しよう. ドライバーがメッセージ集合 $\eta$ に対し て形成する主観的期待の集合 $\Pi(\eta)$ を，確率密度関数 の組 $\Pi(\eta)=\left\{\pi_{s}(e) ; e \in \eta\right\}$ により表現する. 厳密には, ドライバーの主観的期待はすべてのメッセージ $e$ を確率 変数として同時に含む多次元確率密度関数で表現でき る.しかし，言語的に表現されるメッセージを 1 元的な 確率変数として表現することは困難であり，メッセージ 集合全体に対する主観的期待を単一の多次元確率密度関 数により表現することは不可能である. ドライバーが合 理的期待を形成すれば，1 次元確率密度関数により表現 される主観的期待は, 多次元確率密度関数で表現される 主観的期待の条件付き確率密度関数に一致する. 本研究 は交通情報の長期的な経路誘導効果を分析することを目 的としており, 主観的期待を 1 次元確率密度関数の組に より表現しても実用的には問題がないと考える.

公共主体がメッセージ $\hat{e}$ を通知したとしよう。この時, ドライバー $s$ の経路 $a$ に対する期待効用 $V\left(\widehat{\omega}_{a s} ; \pi_{a s}(\hat{e})\right)$ は，主観的期待の集合 $\Pi(\eta)$ に含まれる主観的期待 $\pi_{a s}(\hat{e})$ を用いることにより以下のように表現できる.

$$
V\left(\widehat{\omega}_{a s} ; \pi_{a s}(\hat{e})\right)=\int U\left(\tau_{a}, \widehat{\omega}_{a s}\right) \pi_{a s}\left(\tau_{a} ; \hat{e}\right) d \tau_{a} \cdots
$$

ドライバーは，期待効用を最大にする経路を選択する.

$$
\gamma_{s}^{*}\left(\widehat{\omega}_{a s} ; \pi_{s}(\hat{e})\right)=\arg \max _{a}\left\{V\left(\widehat{\omega}_{a s} ; \pi_{a s}(\hat{e})\right)\right\} \cdots \cdots(4)
$$

記号 arg は, 式( 4 )の右辺を最大にする経路を指示する. 情報構造 $\hat{\mu}$ とメッセージ $\hat{e}$ に対する主観的期待 $\pi_{a s}(\hat{e})$ の下で, すべての通過ドライバーが選択した経路の集合 を $\left.\gamma^{*}(\hat{\mu} ; \pi(\hat{e}))\right\}_{s \in \hat{s}}$ と定義する. 情報構造 $\hat{\mu}$ は私的情報 により構成されており, 各期のドライバーの経路選択 
$\gamma^{*}(\hat{\mu} ; \pi(\hat{e}))$ を事前に予測することは不可能である.

\section{(4) 学習過程と合理的期待形成}

ある時点で，公共主体が交通情報の提供を開始したと しよう. 初期時点で, ドライバーは交通情報に対してあ る初期期待を形成する. その状態は個人によって多様に 異なる．ドライバー $s$ があるメッセージ $e$ のもとで経路 選択を行い，現実の走行時間が事前に予測した主観的期 待 $\pi_{a s}\left(\tau_{a} ; e\right)$ と異なることに気づいたとしよう. その 結果, 彼は新しく獲得した情報を用いてメッセージ $e$ に 対する主観的期待 $\pi_{a s}\left(\tau_{a} ; e\right)$ を修正する. ドライバー は経路選択を繰り返し，それ之同時に走行結果に基づい て主観的期待 $\pi_{a s}\left(\tau_{a} ; e\right)$ を逐次更新する. RE 仮説は, ドライバーのメッセージ $e$ に対する主観的期待 $\pi_{a s}\left(\tau_{a}\right.$; e) と,メッセージ $e$ が提示された場合に実現する走行 時間の客観的分布 $v_{a}\left(\tau_{a} ; e\right)$ の双方が, 長期的な学習過 程の結果として同時に $\mathrm{RE} \pi_{a}^{*}\left(\tau_{a} ; e\right)$ に収束することを 主張する. 筆者等は走行時間関数がリフシッツ連続性条 件を満足し，ドライバーが合理的主体であれば，任意の 初期期待が RE に収束するような学習ルールが存在す ることを示した5゙. そこでは，長期均衡としてすべての ドライバーが RE $\pi^{*}(e)=\left\{\pi_{a}^{*}\left(\tau_{a} ; e\right)\right\}_{a \in \delta_{s}}$ を形成したよ うな状況を合理的期待均衡 (Rational Expectations Equilibrium：REE と略す）と呼んでいる.

\section{（5） 交通情報の中立命題}

交通情報がドライバーの経路誘導効果を持つために は，ドライバーが各メッセージに対して異なった RE を形成しなければならない，換言すれば，異なったメッ セージの下で実現する客観的な走行時間が互いに異なっ た確率分布に従わなければならない. ドライバーが交通 情報の下で経路選択を繰り返し, 主観的期待と経路選択 の変更を繰り返す．交通情報の信頼性も変化する，長期 学習の結果, ドライバーが RE を形成したとしよう. この時，「交通情報は，長期においても何らかの情報的 役割（Informational role of information）を果たしうる 汃という疑問が生じる。交通情報が「情報」として実 質的に機能しない場合，交通情報は中立的（neutral） であると呼ぶ。

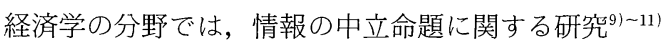
が蓄積されている. 合理的期待均衡が成立する場合, 将 来財市場に参加する主体が獲得した財の将来価格に関す る情報はその財の現時点での市場価格に反映され, 結果 的に主体が獲得した情報が「情報」としての役割を果た さなくなる. 合理的期待均衡に関わる文献を通じて, 極 めて幅広い分野において, 情報の中立命題が成立するこ とが確認されている，交通情報がドライバーの経路誘導 効果を発揮するためには，「交通情報の中立命題」が成 立しないことが前提となる．ドライバーが合理的でない と考えれば，この種の命題が問題になることはない，む
しろ，重要なことは「ドライバーがREを形成したとし ても，交通情報に経路誘導効果が存在するか否か」とい う点にある．本論文では，経路誘導問題において交通情 報の中立命題が成立するか否かという問題に対して $1 つ$ の科学的アプローチを試みることとする.

市場価格が需要と供給の関係で求まるように, 経路誘 導問題の場合, 各経路の走行時間は経路に対する需要と 供給条件の相互作用の結果として求まる. 主体が将来財 を購入する場合, 財の現在価格は市場で事前に観察でき, 市場価格が将来価格に関する情報を他の主体に伝達する 役割を果たす、経路誘導問題の場合，ドライバーが各経 路の走行時間を事前に知りえず，市場価格のような役割 を果たす情報が存在しない。したがって，経路誘導問題 における情報の中立命題を市場均衡に関する議論と同じ 枠組の中で検討することはできない，本研究では，交通 情報の中立性を, 個々のメッセージが何等追加的な情報 をもたらさない状態として定義する。すなわち，任意の $e, e^{\prime} \in \eta\left(e \neq e^{\prime}\right)$ と十分小さな $\varepsilon$ に対して

$$
\left.\begin{array}{l}
\left\|\pi_{a}^{*}\left(\tau_{a} ; e\right)-\pi_{a}^{*}\left(\tau_{a} ; \phi\right)\right\|<\varepsilon \\
\left\|\pi_{a}^{*}\left(\tau_{a} ; e\right)-\pi_{a}^{*}\left(\tau_{a} ; e^{\prime}\right)\right\|<\varepsilon
\end{array}\right\}
$$

が成立する時，交通情報が中立であると呼ぶ。ここに， $\left\|\pi_{a}^{*}\left(\tau_{a} ; e\right)-\pi_{a}^{*}\left(\tau_{a} ; e^{\prime}\right)\right\|=\sup _{\tau_{a}}\left\{\mid \pi_{a}^{*}\left(\tau_{a} ; e\right)-\pi_{a}^{*}\left(\tau_{a} ;\right.\right.$ $\left.\left.e^{\prime}\right) \mid\right\}$ である. 交通情報に対して実現する走行時間分布 に変化が生じなければ，交通情報はもはや「情報」とし て機能しない。交通情報によりドライバーの経路選択を 誘導しようとする試み自体が長期的には意味をなさなく なる．中立命題が成立する場合，ドライバーが REを 形成しえない極めて短期間のみ, 交通情報が誘導効果を 発揮しうることとなる。一方, 中立命題が成立しない場 合，情報提供は長期間にわたって実質的な効果をあげう る．交通情報による経路誘導問題の難しさは，実現する 走行時間分布自体が, ドライバーの経路選択, 期待形成 の結果として内生的に求まる点にある. 交通情報の信頼 性自体が，ドライバーのリスクに対する態度，その時々 の気まぐれ (私的情報) の分布等, ドライバーの選好の 特性やその分布により影響を受ける。交通情報の中立命 題に関しては 6. の数値実験を通じて検討する.

\section{4. 経路選択・期待形成モデルの定式化}

\section{（1）経路選択行動モデル}

本分析では筆者らによる REE 形成モデルを用いる が，その内容は以下で述べるシミュレーションの内容と 密接に関連している，そこで， REE 形成モデルを本分 析の目的に即して再定式化しておく. ドライバーの期待 形成を考える場合, リスクに対する態度を明示的に記述 する必要がある．ドライバーが危険中立的（走行時間の 確実性を考慮しない) であれば，平均走行時間に関する 
期待形成のみが問題となる．危険回避的であれば，経路 走行時間分布に関する期待形成をモデル化する必要があ る. 以下ではドライバーの危険回避行動をモデル化でき るように，走行時間分布に対する期待形成を明示的に考 慮する．ドライバーの経路選択確率が互いに独立であれ ば，リンク交通量の分布を正規分布で近似できる4). 線 形走行時間関数の場合，走行時間は正規分布に従う. 非 線形走行時間関数の場合，走行時間が正規分布に従う保 証はないが正規分布は任意の確率分布の 2 次モーメント までの近似と考えることができる．ドライバー $s, s^{\prime} \in S$ の私的情報の独立性 $\left(E\left[\omega_{a s}, \omega_{a^{\prime} s^{\prime}}\right]=0\left(a \in \delta_{s}, a^{\prime} \in \delta_{s^{\prime}}\right)\right)$ を仮定する．私的情報はドライバーのその時々の経路選 択に影響を与える偶然的・局所的な要因を表わす。ドラ イバーは私的情報により当該期における各経路の効用の 期待効用水準からのかい離の程度を判定する。ここでは $\omega_{\text {as }}$ が効用値の変動を表現していると考える．いま，絶 対危険回避度一定の効用関数 ${ }^{12)}$

$$
\begin{aligned}
U\left(\tau_{a}, \omega_{a s}\right)= & -1+\exp \left\{-\zeta\left(\tau_{a}-E_{s}\left[\tau_{a}\right]\right)\right\} \\
& -E_{s}\left[\tau_{a}\right]+\omega_{a s} \ldots \ldots \ldots \ldots \ldots \ldots \ldots \ldots
\end{aligned}
$$

を仮定する.ここに， $E_{s}\left[\tau_{a}\right]$ は主観的期待 $\pi_{s}\left(\tau_{a} ; e\right)$ に 関する $\tau_{a}$ の期待値, $\zeta$ : 絶対的危険回避度 $\left(U^{\prime \prime} / U^{\prime}\right)$ である. 効用は時間単位で計測され，右辺第 2 項は期待 值からのかい離に対する効用の偏差を表している．ドラ イバー $s$ がメッセージ $e$ に対して想定する経路 $a$ の期待 効用 $V\left(\omega_{a s} ; \pi_{a s}(e)\right)$ を期待值 $E_{s}\left[\tau_{a}\right]$ の近傍でテーラ 展開する. この時, 期待効用を走行時間の（主観的）期 待値 $\pi_{1 a s}(e)\left(=E_{s}\left[\tau_{a}\right]\right)$ ，（主観的）分散 $\pi_{2 a s}(e)$, 私的 情報 $\omega_{a s}$ の加法和で近似できる.

$$
V\left(\omega_{a s} ; \pi_{a s}(e)\right)=-\pi_{1 a s}(e)-\frac{1}{2} \zeta \pi_{2 a s}(e)+\omega_{a s}
$$

ドライバーは期待効用（7）を最大にする経路を選択す る．交通情報の提示がドライバーの経路誘導に及ぼす効 果を検討するためには，各メッセージ $e \in \eta$ に対してド ライバーがどのような主観的期待 $\pi_{1 a s}(e), \pi_{2 a s}(e)$ を形 成するかを分析すればよい.

\section{（2）期待形成モデル}

客観的走行時間分布亡主観的期待はともに 1 次元正規 分布に従うと仮定する. ドライバー $s$ がメッセージ $e$ の 下で形成した $t$ 期の主観的期待 $\pi_{a s}^{t}(e)$ を 2 つ舟数 (平 均値 $\pi_{1 a s}^{t}(e)$ と分散 $\left.\pi_{2 a s}^{t}(e) / 2\right)$ で表現する. 彼が $t$ 期ま でにメッセージ $e$ のもとで経路 $a \in \delta_{s} を n_{a s}(e)$ 回利用 したとしよう， $e$ の下で経験した走行時間実績值の集合 を $\tilde{\tau}_{a s}^{t}(e)=\left\{\tilde{\tau}_{a s}^{1}, \tilde{\tau}_{a s}^{2}, \cdots, \tilde{\tau}_{a s}^{n_{a s}} ; e\right\}$ と表わす. $t$ 期におい て $\hat{e}$ が提示され，彼は主観的期待 $\pi_{s}^{t}(\hat{e})$ に関して期待 効用を最大にする経路 $a$ を選択し，その結果新しい経 験情報 $\tilde{\tau}_{a s}^{t}$ が $\tilde{\tau}_{a s}^{t}(\hat{e})$ に付加される．新しい $\tilde{\tau}_{a s}^{t+1}(\hat{e})$ に 基づいてドライバーは主観的期待 $\pi_{a s}^{t}(\hat{e})$ を更新し, $t+$
1 期の主観的期待 $\pi_{a s}^{t+1}(\hat{e})$ を形成する. 㛜密に言えば, 新しい経験情報を獲得すれば，メッセージ集合 $\eta に$ 対 する主観的期待の組 $\Pi(\eta)$ を同時に修正することがで きる. 主観的期待の同時学習過程を表現するには，3. で言及したような多次元確率密度関数の学習過程をモデ ル化する必要がある. 本研究では操作性の高い期待形成

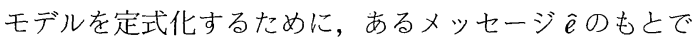
の経路 $a$ の走行経験に基づいて, ドライバーはメッセー ジ $\hat{e}$ に対する主観的期待 $\left(\pi_{1 a s}^{t}(e), \pi_{2 a s}^{t}(e)\right)$ のみを修 正し，それ以外の主観的期待は更新しないと考える.

筆者らが提案したベイズ学習モデルを用いれば，ドラ イバーの学習過程を $t$ 期の新しい経験情報 $\tau_{a s}^{t}$ を用いて 主観的期待 $\left(\pi_{1 a s}^{t}(e), \pi_{2 a s}^{t}(e)\right)$ を逐次更新するルールと して記述できる5),13).

$$
\begin{aligned}
\pi_{1 a s}^{t+1}(e)= & \pi_{1 a s}^{t}(e)+\frac{1}{\nu_{0}+n_{a s}^{t}(e)} \cdot\left(\tau_{a s}^{t}-\pi_{1 a s}^{t}(e)\right) \\
\pi_{2 a s}^{t+1}(e)= & \pi_{2 a s}^{t}(e)+\frac{1}{\alpha_{t}(e)}\left\{\eta_{a s}^{t}(e)\left(\pi_{1 a s}^{t}(e)-\tau_{a s}^{t}\right)^{2}\right. \\
& \left.-\frac{\pi_{2 a s}^{t}(e)}{2}\right\} \ldots \ldots \ldots \ldots \ldots \ldots \ldots \ldots \ldots \ldots \ldots \ldots \ldots \ldots \ldots \ldots \ldots \ldots
\end{aligned}
$$

ここに, $\eta_{a s}^{t}=\nu_{a s}^{t-1}(e) / \nu_{a s}^{t}(e), n_{a s}^{t}(e): t$ 期末までに $e$ の下で当該経路を走行した回数, $\alpha_{t}(e)=\alpha_{0}+n_{a s}^{t}(e) / 2$, $\nu_{a s}^{t}(e)=\nu_{0}+n_{a s}^{t}(e) ， \nu_{0}, \alpha_{0}$ : 定数である. $t+1$ 期におけ る主観的期待値は， $t$ 期における主観的期待值 $\pi_{1 a s}^{t}(e)$, $\pi_{2 a s}^{t}(e)$ と $t$ 期における主観的期待の誤差（走行時間の 実績值と主観的期待値との差）を用いて更新される. $t$ 期で選択しなかった残りの経路 $j\left(\in \delta_{s}\right) \neq a$ の主観的期 待は, その経路が利用されるまで更新されない。式( 8 ) において $t$ が十分大きくなれば，主観的期待を $\pi_{1 a s}^{t}(e)$ $\simeq \tilde{\tau}_{a s}^{t}(e), \pi_{2 a s}^{t}(e) \simeq \widetilde{s}_{a s}^{2 t}(e) / n_{a s}^{t}(e)$ と近似できる. $\tilde{\tau}_{a s}^{t}(e)$ 之 $\tilde{s}_{a s}^{2 t}(e) / n_{a s}^{t}(e)$ は, それぞれ標本平均, 標本分散であ る. ドライバーが経路選択を十分多く繰り返せば，彼の 平均時間，分散に関する主観的期待は客観的に実現する 標本平均, 標本分散に漸近し, 最終的にREを形成する.

\section{5. 経路誘導方法に関する検討}

\section{（1）予測メカニズムの設計}

ネットワーク上に配置したセンサーにより通過交通量 を各期の期首に测定し，当該期に実現する各経路の走行 時間を予測する問題を考えよう. 地点 $i(i=1, \cdots, n)$ で $t$ 期の期首までに観測されたモニタリング情報（交通 量）を $\chi^{t}=\left\{x_{i}^{k} ; i=1, \cdots, n, k=t, t-1, \cdots\right\}$ と表す. 公 共主体は $\chi^{t}$ を用いて各メッセージ $e \in \eta$ を提供した場 合に実現する経路走行時間の分布 $\Psi\left(\chi^{t} ; e\right)=\left\{\Psi_{a}\left(\tau_{a}\right.\right.$ ； $\left.\left.\left.\chi^{t}, e\right): a \in \Delta\right)\right\}$ を予測する. 予測メカ二ズムを $\Psi\left(\chi^{t}, e\right)$ $=\Gamma\left(\chi^{t} ; \Upsilon(e), \eta\right)$ と表現する. $\Delta$ は経路集合, $Y(e)$ は メッセージ $e$ に対するドライバーの反応行動を予測する モデルである．公共主体はモニタリング情報 $\chi^{t}$ と予測 
モデル $Y(e)$ を用いてメッセージ $e$ を提供した場合に実 現する実走行時間分布 $\Psi\left(\chi^{t}, e\right)$ を予測する. ドライバー は公共主体が獲得したモニタリング情報を知ることはで きない.したがって，ドライバーが予測する走行時間分 布 (合理的期待) $\pi^{*}(e)$ と公共主体が予測する走行時 間分布 $\Psi\left(\chi^{t}, e\right)$ は一致しない。このような情報の非対 称性が存在するため, 公共主体はドライバーより正確に 実走行時間分布を予測することが可能となる.

予測メカニズムの設計に関しては種々の手法が適用可 能である．簡便で実用的な予測メカニズムを設計するた めには今後の研究を待たざるをえないが, 本研究では, 以下の代替的な予測メカ二ズムを用いて交通情報の有効 性を検討する．すなわち；1）経路走行時間を正確に予 測できるメカニズム $\left.\Gamma^{* *} ， 2\right)$. 合理的期待形成を考慮し た経路選択モデル4)を用いる予測メカニズム $\left.\Gamma^{*}, 3\right)$ 等 時間配分の結果を用いるメカ二ズム $\Gamma^{\circ}$ を考える． $\Gamma^{* *}$ は，公共主体がドライバーの私的情報を完全に把握して いるような理想的な予測メカニズムを意味する. 公共主 体がドライバーの私的情報を把握できない以上， $\Gamma^{* *}$ を実際に構築することは不可能である.しかし，6.で 行うシミュレーション実験では, 理想的メカニズムを仅 想的に構築することはできる. 理想的メカニズムを用い た思考実験は，交通情報の効果や情報ルールの望ましさ を比較・検討するための基準を与える． $\Gamma^{*}$ は，公共主 体は私的情報を観測できないが，合理的期待は観測でき ると考えた実際的な予測メカニズムである.この場合， 公共主体は情報 $e$ のもとで実現する当該期の走行時間を 正確に予測することはできないが，その期待值は計算で きると考える． $\Gamma^{\circ}$ は，モニタリングされた交通量を各 経路に等時間配分するメカニズムである. この場合, 交 通情報に対するドライバーの反応行動を考慮しておら ず，3つの中では最も単純な方法である. 予測メカニズ ムとしては，この他にも種々の方式が可能である. 特に, モニタリングと情報提供の同期化等を考慮した動的配分 モデルの開発, リアルタイムに計算可能な簡便な方法論 の開発等が今後必要となろう.

\section{（2）情報提供ルールの設計}

情報提供ルール $\Lambda$ は，予測結果 $\left\{\Psi\left(\chi^{t}, e\right) ; e \in \eta\right\}$ を 入力しメッセージ $\hat{e}$ を出力するシステムである．情報提 供ルールは，メッセージ集合 $\eta$ との中からドライバー

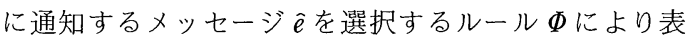
現される. 選択ルールを $\hat{e}=\Phi\left(\Psi\left(\chi^{t}, e\right) ; e \in \eta\right)$ 亡記述 する. 情報提供ルールの設計にあたっては，この他にも （a）情報を受け取るドライバーを差別化するか，（b） 情報を提供する期間をに゙う設定するか，等について検討 する必要がある.（a）は，ドライバー全員に対して情報 を提供するか否かという問題である.これと関連して情 報の価格設定等も今後重要な検討課題となろう。また, （b）と関連して「情報を常に各期において提供するの か」，「渋滞情報のようにある状態が発生したときだけ与 えるのか」等の問題がある. 現在のところ, 以上の課題 に関する研究例はほとんどなく, 情報提供ルールに関し ても今後解決すべき多くの問題が残されている. 本研究 では交通情報による経路誘導の可能性を検討することを 目的としている. 以下の数値計算事例では, 情報ルール の詳細な決定問題には立ち入らず，メッセージに含まれ る情報の多寡がドライバーの経路選択に及ぼす影響につ いて分析するにとよ゙める.

\section{（3）経路誘導効果の評価}

公共主体が望ましい経路誘導システム $\theta=(\Gamma, \Lambda)$ を 設計する場合, ビのような評価規範を設定すべきかが重 要となる. 評価の視点として，1）道路ネットワークの 機能性に着目する方法，2）ドライバーの厚生水準に着 目する方法に大別できる．1）は，道路ネットワーク全 体の機能性を, 例えば信頼性という視点から評価する方 法である ${ }^{14)}$. REE モデルを用いれば経路走行時間の確 率分布自体を予測することができる。したがって，ネッ トワークの信頼性評価の視点から, 経路誘導効果を分析 することも可能である. 2) の立場は, 個々のドライバー の愿生状態を集計して経路誘導施策の望ましさを検討す る方法である．特に，交通情報のドライバー間での差別 化や情報の提供ルールに関してきめ細かく検討するため には，個々のドライバーの厚生水準に関する評価が不可 欠である.このような問題意識のもとに, 本研究では後 者の立場から経路誘導施策の評価を試みる.

個々のドライバーの厚生状態を評価する場合，1）ド ライバーの事前の主観的期待効用を用いる，2）事後に 実際に獲得した効用値に着目するという2つの考え方が ある. 前者は, 経路選択の判断の時に想定した事前の効 用水準を用いてドライバーの厚生を評価する考え方であ る. ある期の期首に私的情報值が $\widehat{\omega}_{s}$ に確定し, 経路選 択の事前・事後を通じてその值が変化しないと考える. さらに，ドライバーは合理的期待を形成していると考え よう.この時, メッセージ $\hat{e}$ 下で当該期に選択した経路 $\hat{a}$ の事前の期待効用 $V\left(\widehat{\omega}_{\hat{a} s} ; \pi_{\hat{a}}^{*}(e)\right)$ は

$$
V\left(\widehat{\omega}_{\hat{a} s} ; \pi_{\hat{a}}^{*}(e)\right)=-\pi_{1 a}^{*}(\hat{e})-\frac{1}{2} \zeta \pi_{2 a}^{*}(\hat{e})+\widehat{\omega}_{\hat{a} s} \cdots \cdots(9)
$$

と表わされる. 一方, 式( 6 ) より事後の確定効用は

$$
\begin{aligned}
U\left(\tau_{\hat{a}}, \widehat{\omega}_{\hat{a} s}\right)= & -1+\exp \left(-\zeta\left(\tau_{\hat{a}}-E^{*}\left[\tau_{\hat{a}}\right]\right)\right) \\
& -E^{*}\left[\tau_{\hat{a}}\right]+\widehat{\omega}_{\hat{a} s} \ldots \ldots \ldots \ldots \ldots \ldots \ldots
\end{aligned}
$$

と表わされる. 一般にある期に選択した事前の期待効用 と事後の効用値は一致しない。事前・事後の効用值を計 測するうえで問題となることは，主観的期待と私的情報 $\widehat{\omega}_{a s}$ の值を直接観察することができない点にある.

RE 仮説の下では，長期的定常状態においてドライ バーの想定する走行時間分布は事後に実現する走行時間 
分布に一致する. したがって，長期間にわたって経路選 択を繰り返すドライバーの事前の期待効用値と事後に確 定する効用の定常的平均値は一致する. しかも, ドライ バーの主観的期待と走行時間の客観分布が一致すれば, 実際に実現する走行時間の確率分布を用いてドライバー の期待効用を計測できる．ドライバーが $\mathrm{RE}$ を形成し ていない場合, 公共主体が彼の主観的期待・私的情報を 観測することはできず，ドライバーの立場から経路誘導 効果を評価することは不可能となる。いま, 経路誘導シ ステム $\theta$ のメッセージ $e$ に対するドライバーの定常状態 における平均効用 $E V_{s}(e ; \theta)$ を次式のように定義する.

$$
\begin{aligned}
& E V_{s}(e ; \theta)=E_{\omega_{s}}\left[\max _{a}\left\{V\left(\omega_{a s} ; \pi_{a}^{*}(e)\right)\right\} ; \theta\right] \\
& =\sum_{a} \int_{-\infty}^{\infty} V\left(\omega_{a s} ; \pi_{a}^{*}(e)\right) \phi\left(\omega_{a s}\right) d \omega_{a s} . \\
& \quad \prod_{a^{\prime} \neq a} \int_{-\infty}^{\bar{v}_{a^{\prime} s}} \psi\left(\omega_{a^{\prime} s}\right) d \omega_{a^{\prime} s} \ldots \ldots \ldots \ldots \ldots \ldots \ldots \ldots \ldots
\end{aligned}
$$

ここで, $\tilde{v}_{a^{\prime} s}=\tilde{c_{a}}(e)-\tilde{c_{a^{\prime}}}(e)+\omega_{a^{\prime} s}, E_{\omega_{s}}$ は私的情報 $\omega_{s}$ に関する期待値, $\tilde{c_{a}}(e)=-\pi_{1 a}^{*}(e)-1 / 2 \cdot \zeta \pi_{2 a}^{*}(e)$ : 事前 の期待効用の確定項である. ドライバーの平均効用を用 いて社会的厚生関数を定義しよう. 経路誘導システム $\theta$ においてメッセージ $e$ を受け取る相対頻度を $\beta_{s}(e ; \theta)$ と表す. この時, 社会的厚生関数 $S W(\theta)$ は

$$
S W(\theta)=\sum_{s} \sum_{e} \beta_{s}(e ; \theta) E V_{s}(e, \theta)
$$

と表せる. 望ましい経路誘導システムとは, 社会的厚生 関数(12) をできる限り大きくしうる $\hat{\theta}=\{\hat{\Gamma}, \widehat{\Lambda}\}$ として 求まる．6. では，代替的な予測入カ二ズム $\Gamma$, 情報提 供ルール $\Lambda$ を組合わせたような経路誘導システムをい くつか想定し, 交通情報の提供がドライバーの社会的厚 生に及ぼす影響について考察する.

\section{6. 数值計算事例}

\section{（1） 数値計算の概要}

公共主体による交通情報の提示が，ドライバーの経路 選択に及ぼす影響について分析する。図一1に示した例 題で, 分岐点 $\mathrm{A}$ を通過するドライバーに交通情報を提供 する問題を考える. 各期の通過交通量 $Q$ は確率変数で あるが, 経路誘導システムの設計問題に分析の焦点を絞 るため, 各期を通じて通過交通量は一定（100台）亡考 える.これらの交通は同時に経路選択を行い，期間中に 経路利用を終了すると考える. ドライバーは危険中立的 $(\zeta=0.0)$ であると仮定する. すなわち，ドライバー はりスクを評価せず, 期待走行時間に基づいて経路選択 を行うと考える. 各ドライバーの経路 1 , 経路 2 に対す る初期期待を $N(50,0)$, 私的情報 $\omega_{a s}$ はワイブル分布 $W(0,10)$, 各経路の内々交通は互いに独立な正規分布

\begin{tabular}{|c|c|c|}
\hline & 選択ルール $\Phi$ & メッセージ集合 $\eta$ \\
\hline$\Lambda_{a}$ & $\begin{array}{l}\text { 各経路の期待走行 } \\
\text { 時間を通知 }\end{array}$ & $\begin{aligned} \eta= & \left(m_{1}, m_{2}\right) \\
e= & m_{1}: \text { 経路 } 1 \text { が } m_{1} \text { 分 } \\
& m_{1}=\{45,50,55,60\} \\
e= & m_{2}: \text { 経路 } 2 \text { が } m_{2} \text { 分 } \\
& m_{2}=\{45,50,55,60\}\end{aligned}$ \\
\hline$\Lambda_{b}$ & $\begin{array}{l}\text { 選択を推洺する } \\
\text { 経路を通知 }\end{array}$ & $\begin{array}{l}\eta=(1,2) \\
e=1: \text { 経路 } 1 \text { を利用せよ } \\
e=2: \text { 経路 } 2 \text { を利用せよ }\end{array}$ \\
\hline$\Lambda_{c}$ & $\begin{array}{l}\text { 経路 } 1 \text { に関する沿滞 } \\
\text { 情報を提示 }\end{array}$ & $\begin{array}{l}\eta=(1,0) \\
e=1: \text { 経路 } 1 \text { が涉滞 } \\
e=0: \text { それ以外 }\end{array}$ \\
\hline
\end{tabular}
$N(25,10)$ に従う之仮定する. 各経路の走行時間関数を 線形関数 $\tau_{b}=\iota_{b}+v_{b} X_{b}$ で表わす. なお, $\tau_{b}$ : 経路走行時 表一1＼cjkstart情報提供ルールとメッセージ

間, $c_{b}, v_{b}$ : 定数, $X_{b}$ : 経路交通量である. 各リンクの 特性は図一1 に示したとおりである。経路 1 は利便性は 高いが混雑しやすい経路, 経路 2 は若干迂回するが混雑 が生じにくい経路を表わす. 各期の期首に内々交通量が 確定するが，ドライバーはその值を知りえず公共主体の みがその值を知ることができると考えよう。なお，内々 交通のドライバーには交通情報は与えられず，通過交通 のみに交通情報が与えられる.

\section{(2) 経路誘導システムの設計}

a）情報提供ルールと合理的期待形成

情報提供ルールの経路誘導索果を分析するために理想 的な予測メカニズム $\Gamma^{* *}$ を採用しよう。 $\Gamma^{* *}$ を用いた 場合, 公共主体は各期におけるドライバーの主観的期待 $\pi_{s}(e)$ と私的情報值 $\omega_{a s}$ を観測でき，メッセージ $e$ に対 する事前の期待効用（9）と事後の確定効用値（10）を 計算することができる. 現実には，このような理想的メ カニズムを設計することは不可能であるが，シミュレー ション実験では仮想的に構築することができる. 理想的 メカニズムを用いた分析は, 異なる経路誘導システムの 性能を比較評価する基準を与える。一方, 情報提供ルー ルとして 1$)$ 各経路の期待走行時間を（5 分刻みで）通 知するルール $\Lambda_{a}($ ケース a)，2）選択を推奨する経路 を通知するルール $\Lambda_{b}($ ケース b)，3）経路 1 に関する 渋滞情報を提示するルール $\Lambda_{c}($ ケース c) を想定する. 各ケースにおけるメッセージ集合 $\eta$ とメッセージ選択

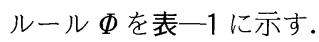

シミュレーションは以下の手順で実施した。 1$)$ 初期 期待 $\pi_{a s}^{0}(e)$ を設定する. 2) 各期ごとに私的情報には ワイブル分布, 内々交通量に正規分布に従う乱数をわり

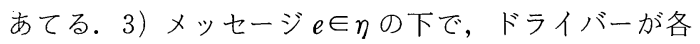
経路に対して想定する期待効用（7）を算定する．4） 各ドライバーが選択する経路を確定する．5）各ドライ バーの経路選択の結果を集計し, 各経路の走行時間を算 定する.6)私的情報值 $\omega_{a s}$ 之選択走行時間を用いて,メッ セージ $e$ に対してドライバーが事後に獲得する確定効用 値（10）を計算する．7）事後の確定効用値を集計し, 


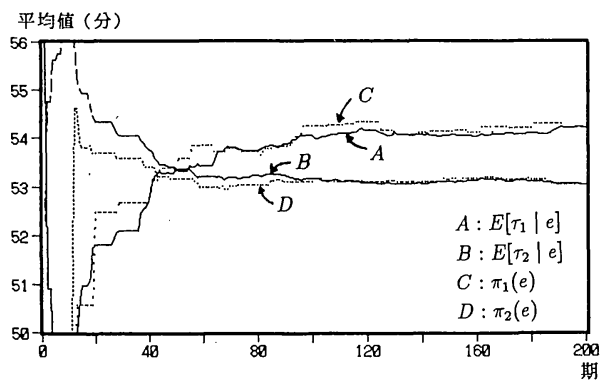

図一2 主観的期待と客観的分布の変化 平均值 (分)

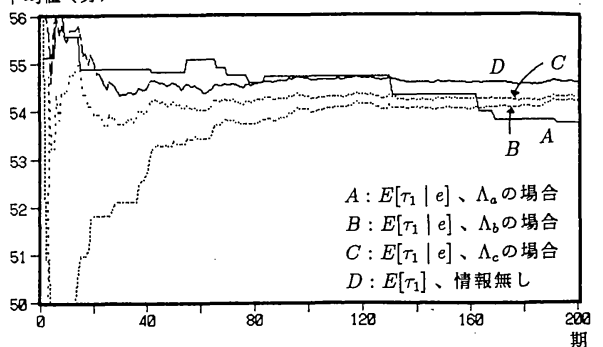

図一3(a) 情報量と経路誘導効果の関係（経路 1 ）

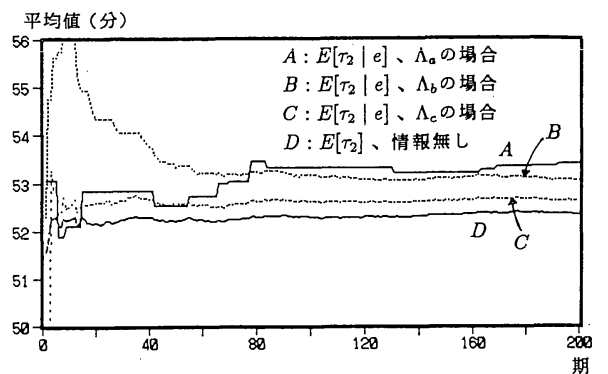

図一3( b ) 情報量と経路誘導効果の関係（経路 2 ）

その值がもっとも大きくなるようなメッセージを選択す る. 8) 式（8）を用いて主観的期待を更新する. 現実 には，このような理想的メカニズムの設計は不可能であ るが，思考実験的に構築することは可能である.

図一2 は，あるドライバーの主観的期待と客観的走行 時間の平均值の時間的変化を示している. シミュレー ションは 400 期まで繰り返したが，200 期までに定常状 態にほぼ到達している，ここでは，200 期までの結果を 示している. この図より主観的期待と客観的平均値は互 いに急速に近接し，合理的期待に収束していくことがわ かる. 経路 1 と経路 2 の平均走行時間は一致せず，等時 間原則は成立していない. 図一3 は情報提供ルール $\Lambda_{a}$ がメッセージ $e=(60,55)$ を選択した期のみをとりあげ, それらの期において実現した客観的走行時間の平均值の 時間的変化パターンを示したものである.（a）は経路 1 , (b) は経路 2 の結果を示しているメッセージ $e=(60,55)$ が提供された期のみを対象として平均值を求めているの で, 平均值の収束は緩慢である. しかし, いずれの情報 システムを用いても, 情報提供により 2 つの経路の平均

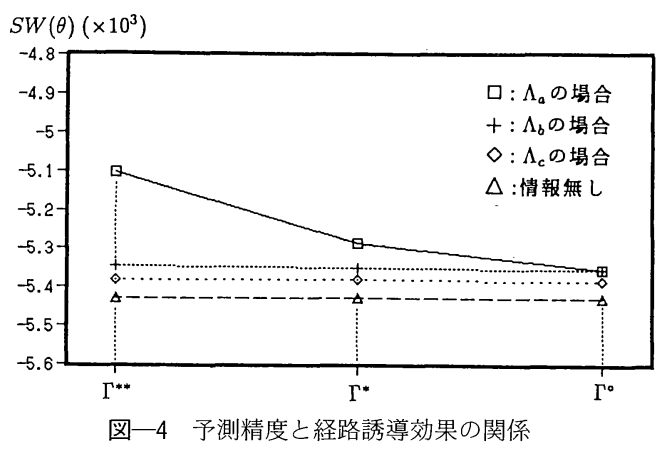

走行時間の格差は減少しており, 情報提供による経路誘 導効果が現われている. すなわち, 交通情報の中立命題 は成立せず，情報提供による経路誘導が長期間にわたつ て可能である.メッセージが伝達する情報量は $\Lambda_{a}$ が最 も多く, $\Lambda_{c}$ が最も少ない.この図より, 経路 1 に関し ては $\Lambda_{a}$ を用いた場合の平均走行時間が最も小さく, 逆 に経路 2 では $\Lambda_{a}$ がもっとも大きな平均走行時間を与え ており, 両経路の平均値の差は一番小さくなっている. より詳細な情報を提供することにより，より等時間配分 に近い交通流が得られている. また，図一4は各情報提 供ルールを用いた場合の社会的厚生関数値 $S W(\theta)$ の変 化を示している．情報量が多くなる程， $S W(\theta)$ は大き くなることが理解できる. 交通情報の精度により経路誘 導効果にビの程度の差異がでるかは, 走行時間関数の形 状, 交通量の日変動の程度, 私的情報の分散等によって 多様に異なる. 経路誘導効果とこれらの諸要因の間の定 量的な関係について分析することは交通工学上非常に重 要な課題であり, 今後の検討課題としたい.

b）予測メカニズムの精度の影響

以上では，公共主体がドライバーの経路選択に関する 完全情報を有していると仮定した. しかし，公共主体は 私的情報 $\omega_{s}$ を観測できない. この種の情報の不完備性 を考慮した場合, 経路誘導問題は格段に複雑になる. 以 下では，予測メカニズムの予測精度の差異がドライバー の経路誘導効果に及ぼす影響について考察する. 予測入 カニズムとして 5.（1）で述べた $\Gamma^{* *}, \Gamma^{*}, \Gamma^{\circ}$ を想定す る. 予測精度はこの順に低下する. $\Gamma^{*}$ を用いた場合の シミュレーションも, 理想的予測システムと同様の手順 で実施できるが，私的情報 $\omega_{s}$ が観測できないため，以 下の点について修正する. ステップ4), 5) において, 各ドライバーの選択経路を確定的に把握できない. 私的 情報 $\omega_{a s}$ が分散入のワイブル分布に従うとし，メッセー ジ $e$ の下でのドライバーの経路選択確率 $p_{a}(e)$ をロジッ トモデルを用いた REEモデル゙)で表現する.

$$
p_{a}(e)=\frac{\exp \left\{\lambda\left[-\pi_{1 a}^{*}(e)-1 / 2 \cdot \zeta \pi_{2 a}^{*}(e)\right]\right\}}{\sum_{b \in \Delta} \exp \left\{\lambda\left[-\pi_{2 b}^{*}(e)-1 / 2 \cdot \zeta \pi_{2 b}^{*}(e)\right]\right\}}
$$


メッセージ $e$ に対する経路走行時間の期待值 $\tilde{\tau}_{a}(e)$ を ロジットモデルを用いて予測する. 経路走行時間は内々 交通の影響を受けるためこの值はドライバーには観測で きず，公共主体のみが観測可能となっている．換言すれ ば，公共主体がドライバーに観測できない $\tilde{\tau}_{a}(e)$ を知 ることができるため, ドライバーの経路誘導が可能とな る. また，公共主体は，私的情報を観測できないため, ステップ6) で各メッセージに対する事後の効用值 (10) を確定的に予測することができない.

事後の確定効用に関する事前の期待値 $E U_{s}(e)$ を

$$
\begin{aligned}
E U_{s}(e ; \theta)= & \sum_{a} \int_{-\infty}^{\infty} U\left(\tilde{\tau}_{a} ; \omega_{a s}\right) \psi\left(\omega_{a s}\right) d \omega_{a s} . \\
& \prod_{a^{\prime} \neq a} \int_{-\infty}^{\tilde{v}_{a^{\prime} s}} \psi\left(\omega_{a^{\prime} s}\right) d \omega_{a^{\prime} s} \ldots \ldots \ldots \ldots
\end{aligned}
$$

と定義しよう.ここに, $U\left(\tilde{\tau}_{a} ; \omega_{a s}\right)$ : 走行時間が $\tilde{\tau}_{a}$ の 時の事後効用である. ドライバーは事前の期待効用に基 づいて経路を選択するが，事後に確定する効用が事前の 期待効用に一致する保証はない. 式 (14) は, 事後の走 行時間の期待值が $\tilde{\tau}(e)$ となることを把握した時に実現 するであろう事後の確定効用の期待值を事前に評価した 結果を示している. 公共主体は事後効用の事前の期待値 （14）を全ドライバーに対して集計した值を用いて集計 値が最も大きくなるようなメッセージを選択する.さら に， $\omega_{a s}$ が独立なワイブル分布に従う時, 式 (14) を積 分することにより次式を得る.

$$
\begin{aligned}
E U_{s}(e)= & \lambda^{-1} \log \sum_{a} \exp \left(\lambda \tilde{c}_{a}(e)\right) \\
& +\sum_{a}\left(\tilde{c}_{a}(e)-\tilde{u}_{a}(e)\right) p_{a}(e)
\end{aligned}
$$

ただし， $\tilde{c}_{a}(e)$ : 事前の期待効用 $(9)$ の確定項, $\tilde{u}_{a}(e)$ $=-1+\exp \left(-\zeta\left(\tilde{\tau}_{a}-E^{*}\left[\tau_{a}\right]\right)\right)-E^{*}\left[\tau_{a}\right]$ : 事後効用 (10）の確定項である. 上式第 1 項はロジットモデルに おける合成効用項, 第 2 項は期待効用值亡事後に確定す る効用値のかり離の期待值を表わしている. なお，ドラ イバーが各期で知り得る情報は $e$ のみであり, 期待走行 時間 $\tilde{\tau}_{a}(e)$ を知ることができない. 換言すれば, 公共 主体は $E U_{s}(e)$ を知ることはできるが, ドライバーは $\tilde{\tau}_{a}(e)$ を知り得ず, ドライバーは事後効用の事前の期待 值 $E U_{s}(e)$ を知り得ない. 本研究ではドライバーの厚 生に基づいて経路誘導システムの評価を行う立場に立つ ており，ドライバーが知り得る情報に基づいてシステム の評価を行う必要がある. 予測メカニズムの精度をドラ イバーの立場から評価するために, 本研究では評価尺度 として社会的厚生関数（12）を用いることとする.

図-4には, 予測メカニズムと社会的厚生関数 $S W(\theta)$ の関係も示している. 予測メカニズムの精度が低下する 程, $S W(\theta)$ の值は低下している. しかし， $\Gamma^{\circ}$ のように それ程予測精度が高くない予測メカニズムを用いても情 報提供により $S W(\theta)$ を増加する効果が現われている.

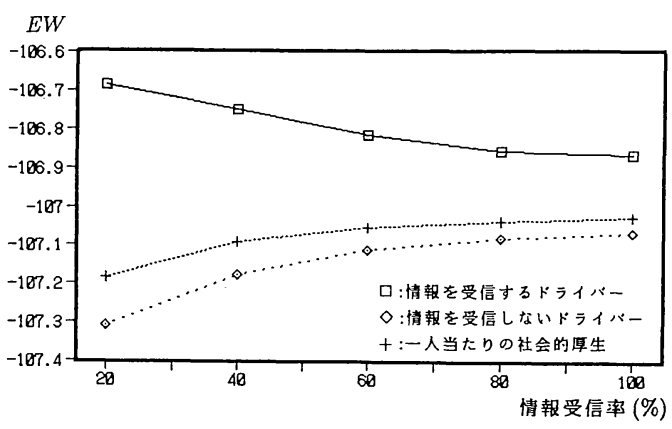

図一5 情報受信率と経路誘導効果の関係

$\left(\Lambda_{b}, \Gamma^{* *}\right.$ の場合 $)$

伝達する情報量が少ないルール $\left(\Lambda_{b}, \Lambda_{c}\right)$ の場合, 予測 メカニズムの精度を向上させても $S W(\theta)$ はそれほよ゙増 加しない. 逆に, 伝達する情報量が多いルール $\Lambda_{a}$ の場 合, 予測精度を向上させることにより $S W(\theta)$ も増加す ることがわかる. 以上の結果は, より詳細な情報提供を 試みるためには，より精度の高い予測メカニズムの開発 が必要となることを示唆している. ただし, 予測精度の 向上と経路誘導効果の関連は, 前述したような道路環境 の諸条件によって多様に異なることが予想される. 情報 システムの経路誘導効果の定量的評価に関しては, きめ 細かな分析を積み上げていくことが必要になる.

c）情報提供の差別化の影響

交通情報を受信するドライバーとそうでないドライ バーに区別しよう．交通情報を受信するドライバーの全 ドライバーに対する比率 $\xi(\%)$ を逐次変化させ，全ド ライバー, 交通情報を受信したドライバー, 受信しなかっ たドライバー 1 人当たりの平均効用 $E W=\sum_{e \in \eta} E V_{s}$ $(e, \theta)$ (式 $(11)$ がどのように変化するかを分析した. その結果を図一 5 に示す. 受信率が大きくなる程, 全ド ライバー 1 人当たりの平均効用は大きくなる. 交通情報 の提示により混雑する経路の混雑状況が緩和されるた め, 交通情報を受信しないドライバーの平均効用は増加 する. すなわち, 情報受信しないドライバーも情報提供 による経路誘導効果にただのり (free ride) することが 可能となる. その結果, 交通情報を受信したドライバー の 1 人当たりの平均効用は受信率が多くなるにつれて減 少していく．情報を受信するドライバーの比率が多くな ればなる程, 社会的厚生は大きくなるが交通情報の 1 人 当たりの経済価值は減少していく，交通情報の価格設定 の問題を検討する場合，交通情報の望ましい受信比率に ついて検討することが必要となろう。

\section{7.おわりに}

ドライバーの期待形成の問題は，ドライバーが考える 経路走行時間の分布が学習過程を通じてどのような $\mathrm{RE}$ に収束するかという問題として把握できる. 公共主体が 
交通情報を提供した場合, ドライバーは各情報(メッセー ジ）の下で主観的期待を形成する。この時, RE は各メッ セージに対する走行時間の条件付き確率密度関数として 与えられる. 公共主体が情報提供を通じてドライバーの 経路誘導を行うためには, 情報の中立命題が成立しない ことが前提となる. 本研究でとりあげた事例は極めて簡 単なものであるが，交通情報の中立命題は成立せず，情 報提供により経路誘導効果を長期的に発揮し得ることが 判明した. 情報提供による経路誘導問題に関しては研究 の蓄積が乏しいのが実情である. 特に, ドライバーの期 待形成の問題を考慮した経路誘導問題に関しては, 著者 らの知る限り本研究がはじめての試みである.この種の 研究は緒についたばかりであり, 交通情報の最適な予測 方法・提供方法に関するより詳細な研究を積み上げるこ とが必要である.なお, 本論文の枠組みの中においても, 紙面の都合により 1) ドライバーの危険回避度と経路誘 導効果の関係, 2) 代替的な予測メカニズム, 情報提供ルー ルの効果比較等, 多くの分析結果を割愛せざるを得な かった.これらの結果に関しては別の機会に発表したい と考える. 今後, 本研究を進展させるためには, モ二タ リング情報をリアルタイムに駆使しうる動的な予測メカ ニズムの開発が重要な課題となる. また, 情報提供の差 別化を図るために交通情報の価格設定の問題を検討する 必要がある. さらに; 交通情報に対するドライバーの反 応行動に関する実証分析も必要となろう.このように本 モデルは多様な発展が可能であり, 本稿で提案した分析 枠組みにより情報提示によるドライバーの経路誘導問題 に対する 1 つの方向付けを示し得たと考える.

\section{参 考 文 献}

1）森津秀夫 ·大原竜也 ·多田典史 $\cdot$ 井上琢弥：経路誘導に
よる交通ネットワークフローの変化に関する分析, 土木 計画学研究・論文集, No. 9, pp. 37〜44, 1991.

2）飯田恭敬・内田 敬・泉谷 透：旅行時間変動による損 失を考慮した適正経路分担交通量, 土木計画学研究・論 文集, No. 8, pp. 177 184, 1990.

3）飯田恭敬・内田 敬：リスク対応行動を考慮した道路網 経路配分, 土木学会論文集, No. 464/NV-19, pp. 63〜72, 1993.

4）小林潔司：不完備情報下における交通均衡に関する研究, 土木計画学研究・論文集, No.8, pp.81〜 88, 1990.

5）小林潔司・藤高勝巳 : 合理的期待形成過程を考慮した経 路選択行動モデルに関する研究, 土木学会論文集, No. 458/IV-18, pp.17〜26, 1993.

6) Aumann, R. : Agreeing to disagree, Annals of Statistics, Vol.14, pp.1236 1239, 1976.

7) Harsanyi, J.C. : Game with incomplete information played by Bayesian' players, I, II , III, Management Science, Vol.14, pp.159 182, 320 334, 486 502, 1967, 1968.

8) Moyal, J.E. : The general theory of stochastic population process, Acta Mathematica, Vol.108, pp.1 31, 1962.

9) Grossman, S. : The Informational Role of Prices, MIT Press, 1989.

10) Hellwig, M.F. : On the aggregation of information in capital markets, Journal of Economic Theory, Vol.22, pp.477 498, 1980.

11) Radner, R. : Rational expectations equilibrium : Generic existence and information revealed by price, Econometrica, Vol.47, No.3, pp.655 678, 1979.

12) Arrow, K.J. : Essays in the Theory of Risk Bearing, Chicago, Markham, 1971.

13）繁枅算男：ベイズ統計入門,東京大学出版会, 1985 .

14）例えば, 飯田恭敬・若林 拓・福島 博 : 道路網信頼性 の近似解析法の比較研究, 土木学会論文集, No.407/N -11, pp.107 116, 1989.

(1992.11.13 受付)

\section{PROVIDING ROUTE GUIDANCE INFROMATION FOR AUTOMOBILE NAVIGATION}

\section{Kiyoshi KOBAYASHI and Osamu IKAWA}

This paper tries to provide a unified framework for understanding how drivers act in response to exogenously provided public route guidance information in the short run; and how they can form rational expectations-which is conditional to route guidance information-from repeated observation of traffic conditions in the long run. The learning is placed in the context of an iterative adjustment process which achieves equilibrium if drivers have rational expectations. Route choice models with rational expectations find a new justification since the models appear as limits of drivers' learning procedures. This paper also addresses to the question of whether route guidance information can convey substantial "information" to drivers even if drivers behave with rational expectations about their environment. The authors' answer is affirmative. The authors also try to propose an analytical framework for investigating the informational role of route guidance information. 